Report No: AUS0001633

Using Remittance Transaction Data for Timely Estimation of the Foreign Worker Population in Malaysia

June 6, 2020

POV

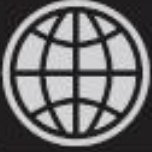


(C) 2020 The World Bank

1818 H Street NW, Washington DC 20433

Telephone: 202-473-1000; Internet: www.worldbank.org

Some rights reserved

This work is a product of the staff of The World Bank. The findings, interpretations, and conclusions expressed in this work do not necessarily reflect the views of the Executive Directors of The World Bank or the governments they represent. The World Bank does not guarantee the accuracy of the data included in this work. The boundaries, colors, denominations, and other information shown on any map in this work do not imply any judgment on the part of The World Bank concerning the legal status of any territory or the endorsement or acceptance of such boundaries.

\section{Rights and Permissions}

The material in this work is subject to copyright. Because The World Bank encourages dissemination of its knowledge, this work may be reproduced, in whole or in part, for noncommercial purposes as long as full attribution to this work is given.

Attribution—Please cite the work as follows: "World Bank. \{YEAR OF PUBLICATION\}. \{TITLE\}. @ World Bank."

All queries on rights and licenses, including subsidiary rights, should be addressed to World Bank Publications, The World Bank Group, 1818 H Street NW, Washington, DC 20433, USA; fax: 202-522-2625; e-mail: pubrights@worldbank.org. 


\title{
Using remittance transaction data for timely estimation \\ of the foreign worker population in Malaysia
}

\author{
Zainab Ali Ahmad, Kenneth Simler and Soonhwa Yi ${ }^{1}$ \\ The World Bank
}

June 2020

\begin{abstract}
Malaysia has been grappling with understanding how many foreign workers reside in the country and thus faces challenges in formulating evidence-based foreign worker policies. This paper investigates how to use micro-level remittance transaction data collected from money transfer service providers to estimate the number of foreign workers. Most foreign workers remit a large portion of their earnings to support family members back home. They are low-income earners, are sensitive to remittance costs, and thus opt for money transfer service providers to remit money rather than regular banks, where transfer services are more expensive. Therefore, the remittance data provide a useful source to conduct the investigation. Existing estimates range from two to five million foreign workers; our results narrow that range considerably, estimating a total of 2.99 million to 3.16 million foreign workers in Malaysia as of 2017-18. State and nationality distributions of foreign workers in our estimates are consistent with the Ministry of Home Affairs data, lending support to the validity of our estimates. Nevertheless, we note that the Bank Negara Malaysia remittance data could potentially underestimate the number of workers in states with low access to money service providers, as well as nationalities that have access to alternative money transfer mechanisms such as commercial banking and informal transfer channels.
\end{abstract}

\footnotetext{
${ }^{1}$ The authors thank Achim Schmillen, Caglar Ozden, Roy van der Weide, Young Eun Kim, Amanina Abdur Rahman, and Alyssa Farha Jasmin for their comments and in-depth discussions on methodologies. We also thank Firas Raad, Rinku Murgai, Philip O'Keefe for their guidance during the preparation of this paper. The paper also benefited from data support and feedback from the Money Services Business Regulation Department of Bank Negara Malaysia, Foreign Workers Division at the Immigration Department of Malaysia, the Ministry of Home Affairs, and the Ministry of Human Resources. For questions and comments, please contact Soonhwa Yi (svi@worldbank.org) or Kenneth Simler (ksimler@worldbank.org).
} 


\section{Introduction}

This paper supplements our earlier report (World Bank, 2020) that estimates the number of foreign workers in Malaysia at $\mathbf{2 . 9 6}$ million to $\mathbf{3 . 2 6}$ million in $\mathbf{2 0 1 7}$ (of which an estimated 40.8-49.3 percent are irregular foreign workers ${ }^{2}$ ). The report has contributed to the literature by spelling out ways to use existing administrative data, including remittance transaction data, in Malaysia to better estimate the total number of foreign workers, encompassing both regular and irregular workers. As an extension of that report, this paper explores another way to use the existing remittance transaction data compiled by the central bank, Bank Negara Malaysia (BNM), to estimate the foreign worker population.

Malaysia has seen rising inflows of low-skilled foreign workers, supporting jobs of higher-skilled natives. A rapid expansion of education levels over the past two decades resulted in Malaysians' job preferences shifting to more skilled jobs, and unemployment rates stayed at a low level owing to rapid economic growth. Inflows of foreign workers, thus, have been responding to domestic labor demand to fill lowskilled, labor-intensive jobs in export-oriented agriculture, manufacturing and domestic service industries (World Bank, 2016). The presence of these workers has led to the creation of higher-skilled jobs for Malaysians and contributed to increased skills premia of Malaysian workers (ibid).

These foreign workers are temporary labor migrants, primarily low-skilled, regulated under Malaysia's work permit system. They enter the country with an employment contract and can stay with the same employer for up to ten years. They are not allowed to change their employers within the country and must return to their home countries after termination of their contract. In principle, therefore, the Ministry of Home Affairs (MOHA), which manages the work permit system, monitors the number of total foreign workers by sector, nationality, and state.

But not all foreign workers are regular, posing challenges in grasping the actual number of foreign workers residing in Malaysia at a given time and thus in formulating relevant policies. There exist three channels for a foreigner to become an irregular worker in Malaysia: (i) to enter Malaysia without a valid work permit and undertake paid jobs, (ii) to enter with a valid work permit, but fail the mandatory medical test and remain in Malaysia, or work with an employer who is unrelated to the valid work permit, and (iii) to work with an expired work permit (or overstayers).

This paper and our earlier report respond to a call for a methodology to estimate the foreign worker population in a systematic and comprehensive manner. MOHA estimates irregular foreign workers based on its sporadic and ad hoc enforcement activities. The Labour Force Survey (LFS) measures some of the foreign worker population but its underestimation is widely recognized, as the LFS sampling is householdbased and does not reach people in communal housing, which is common among foreign workers. Population census-based data include all people who were not born in Malaysia, but foreign workers are only a subset of the total foreign-born population. These official reports as well as other studies have estimated the number of foreign workers ranging widely from two to five million. However, the results

\footnotetext{
${ }^{2}$ Irregular foreign workers are those who are either (i) undocumented or (ii) documented but whose actual employment is out of compliance with their documentation, such as working for a different employer or working with an expired work permit.
} 
from our current study and earlier report (World Bank, 2020) add to the growing evidence that demonstrates a smaller, consistent estimate of around three million foreign workers in Malaysia.

Our results in this paper indicate that the number of foreign workers in Malaysia was between 2.99 million and $\mathbf{3 . 1 6}$ million in 2017-18. State and nationality distributions of foreign workers in our estimates are consistent with $\mathrm{MOHA}$ data, indicating that our estimates are robust. Nevertheless, we note that the BNM remittance data could potentially underestimate the number of workers in states with low access to money service providers (MSPs), as well as nationalities that have access to alternative money transfer mechanisms such as commercial banking and informal transfer channels. This underestimation could be mitigated over time by BNM's greater efforts to lower remittance costs and enhance financial literacy of residents, including foreign workers. In this challenging time of the COVID-19 global pandemic, an expansion of online money transfer services is crucial as a mitigation measure, simultaneously lowering remittance costs and addressing issues of limited accessibility of MSPs among foreign workers.

This paper is organized as follows: the next section briefly paints the landscape of foreign workers, including a survey of available foreign worker estimates. Section 3 presents the data and methodology. Section 4 discusses the results and Section 5 concludes with a discussion on a framework to measure foreign workers in a systematic manner.

\section{The foreign worker landscape}

Official statistics suggest that the foreign worker population is hovering around $\mathbf{2 . 4} \mathbf{- 3 . 2}$ million, but limitations exist. MOHA reports that regular foreign workers are 1.7 million as of March 2018, based on work permit issuance. However, its estimates of irregular foreign workers are based on its ad hoc enforcement activities, suggesting that four out of ten foreign workers are irregular. Taking these two together leads to a foreign worker population of 2.93 million, including 1.3 million irregular workers, in 2018. The LFS captures some of the foreign worker population, including irregulars, estimating 2.43 million foreign workers in total in 2019 , or about 15 percent of the total labor force. Population census-based data of the Department of Statistics Malaysia estimates 3.2 million foreigners residing in Malaysia, but this includes higher-skilled expatriates, their dependents, and all people who were not born in Malaysia.

Foreign workers have become important to fill jobs. LFS data depict the magnitude of the foreign workforce in Malaysia's labor market, albeit imperfectly. Inflows of foreign workers have increased steadily since the 1990s, when the government introduced a system to manage the low-skilled foreign workforce. As shown in Figure 1, the share of foreign workers in total employment increased from 10 percent in 2006-08 to around 15 percent from 2013 onwards. The foreign worker share among the employed youth workforce has increased more rapidly: in 2016 about 26 percent of the total youth employed were foreign workers, compared to about 8 percent in 2006-08. The share of male foreign workers has expanded faster than the female share: while the ratio of foreign to Malaysian employees remained at one to ten over the decade for females, it increased to two to ten for their male counterparts. This gender divide is likely attributable to the design of Malaysia's foreign worker system, which has more vacancies for labor-intensive jobs traditionally held by men. 
Figure 1: Share of foreign workers in the respective employed populations (percent)
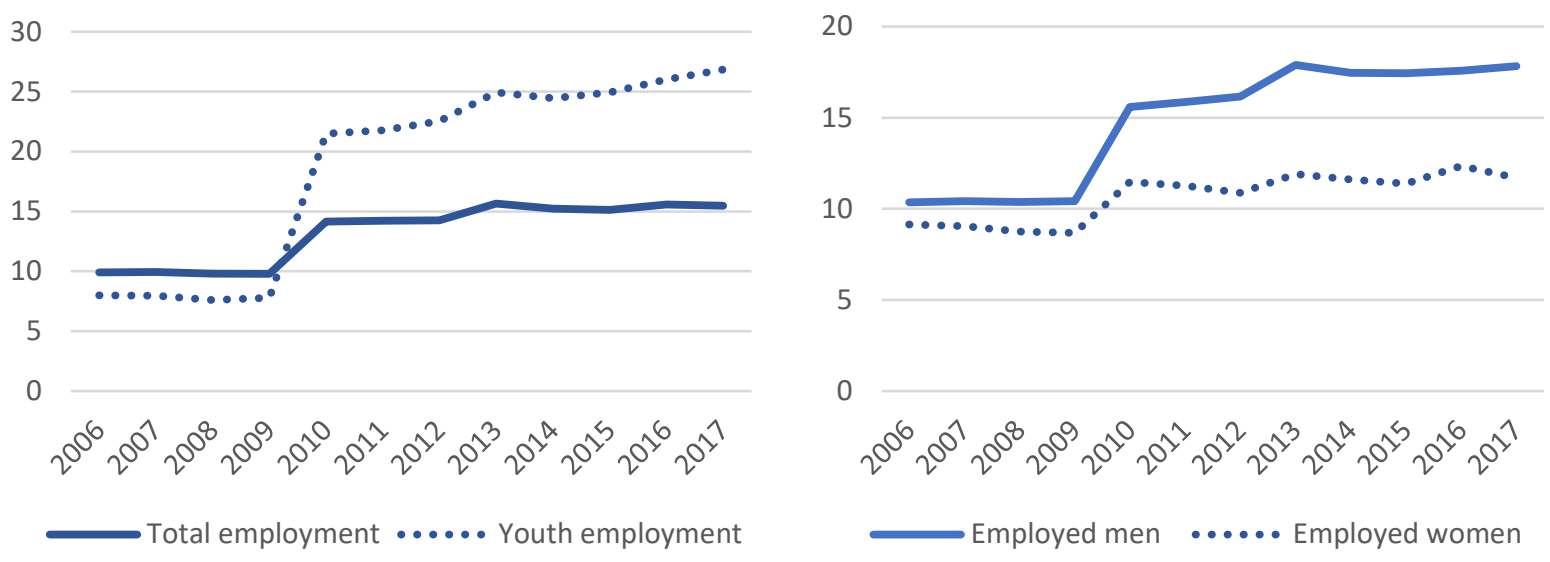

Source: LFS, various years.

Note: Youth refers to those 15 to 24 -years-old.

Indonesians make up the largest share of the foreign worker population, according to MOHA data. Forty percent of foreign workers are Indonesian, followed by Bangladeshi (28 percent) and Nepalese (16 percent) (Figure 2). Anecdotal evidence suggests that Indonesians move to, and work in, Malaysia as irregular foreign workers more than other nationalities, benefiting from the close geographical proximity and Indonesian migrant networks in Malaysia, and therefore the Indonesian foreign worker share could be even larger than indicated by the MOHA data. Corroborating anecdotal evidence is that Indonesia has seen an influx of returning irregular overseas workers from Malaysia because of job losses during the ongoing COVID-19 crisis. ${ }^{3}$ Additional evidence is that the Indonesian government sent aid packages to support Indonesian day laborers in Malaysia-who are highly likely to be foreign workers - who were adversely affected by the Movement Control Order (MCO) implemented by the Malaysian government as a COVID-19 mitigation measure.

Foreign workers are largely concentrated in physically demanding sectors of the economy such as manufacturing, construction and plantations (Figure 3). Foreign workers pick up the '3D' (dirty, difficult, and dangerous) jobs in these sectors that Malaysians stay away from. In 2019, 35 percent of foreign workers were in manufacturing, 22 percent in construction, and 15 percent in services. Studies report, for instance, that the construction sector faces difficulties with filling jobs from the domestic labor force, as local youth avoid the sector because of the low wages, long work hours, physically demanding tasks, and limited career progression. Others argue, however, that the high dependency on foreign workers in the construction sector is associated with the existence of irregular foreign workers (Abdul-Rahman, et. al,

\footnotetext{
${ }^{3}$ More than 64,000 Indonesian foreign workers had returned from Malaysia amid the country's ongoing lockdown since March 18. Source: The Jakarta Post, April 23, 2020, from https://www.thejakartapost.com/news/2020/04/23/high-influx-of-indonesian-migrant-workers-from-malaysiadespite-call-to-stay-amid-outbreak.html.
} 
2012). Foreign workers engage in low value-added activities in general, including in the manufacturing and construction sectors (Del Carpio et al, 2015).

Figure 2: Indonesians make up the majority of foreign workers in Malaysia, but Bangladeshi workers present a rising share (share of foreign workers by nationality, 2019)

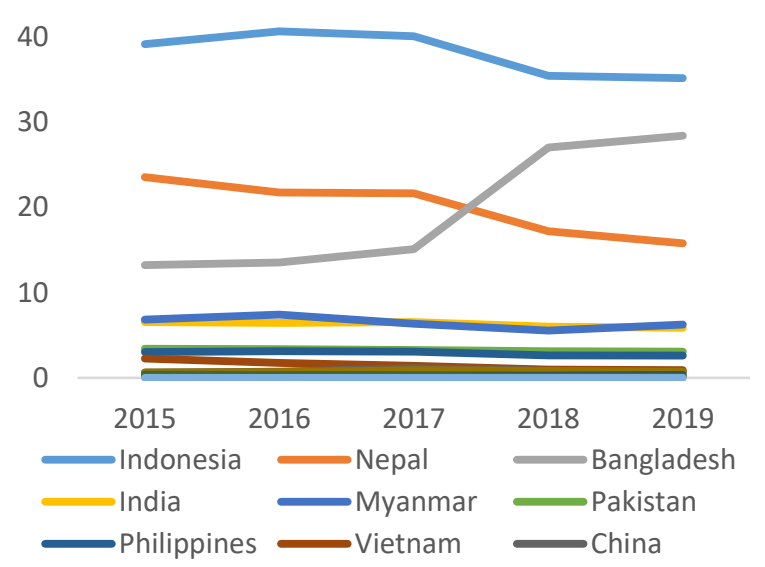

Figure 3: The manufacturing sector remains the key employer, while the plantation sector (construction) saw a decreasing (increasing) share (share of foreign workers by sector, 2019)

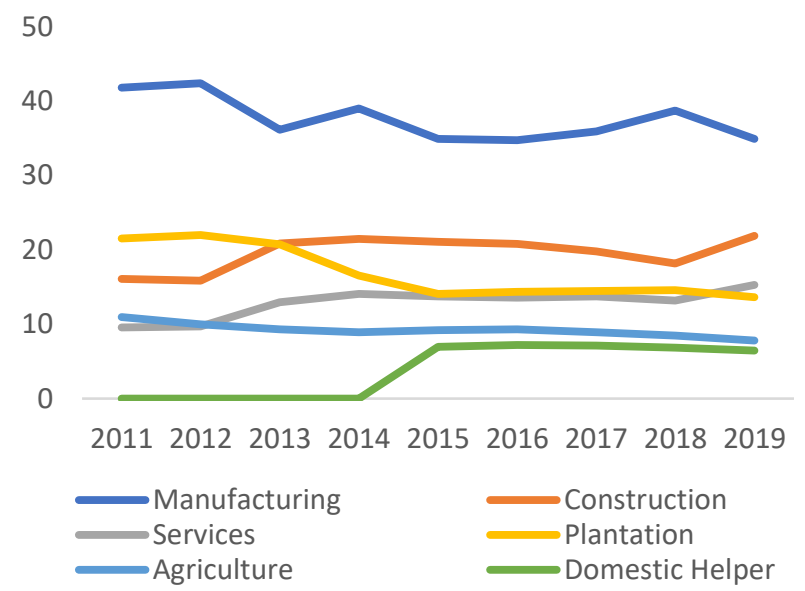

Source: MOHA 2020.

Selangor is the main host state, followed by Johor, Kuala Lumpur, and Pulau Pinang. Selangor hosts 30 percent of the total foreign worker population, consisting of 30 percent Indonesian, 25 percent Nepalese, and 18 percent Bangladeshi workers. As Table 1 shows, about 75 percent of foreign workers in Sabah work in the plantation and agriculture sectors, while most of them in Kuala Lumpur are in the services sector (domestic help, construction and service sectors) and two-thirds of foreign workers in Pulau Pinang are in manufacturing. 
Table 1: Distribution of foreign workers by state and by sector (percent, 2018)

\begin{tabular}{|c|c|c|c|c|c|c|c|c|}
\hline \multirow[b]{2}{*}{$\begin{array}{l}\text { State / Federal } \\
\text { Territory }\end{array}$} & \multirow[b]{2}{*}{$\begin{array}{c}\text { Total } \\
(\%)\end{array}$} & \multicolumn{7}{|c|}{ Sector of employment (percent) } \\
\hline & & $\begin{array}{c}\text { Domestic } \\
\text { Helper }\end{array}$ & $\begin{array}{l}\text { Construc- } \\
\text { tion }\end{array}$ & Services & $\begin{array}{l}\text { Manufac- } \\
\text { turing }\end{array}$ & Plantation & $\begin{array}{l}\text { Agri- } \\
\text { culture }\end{array}$ & Total \\
\hline Selangor & 29.8 & 9.8 & 21.7 & 17.4 & 39.2 & 5.9 & 6.0 & 100 \\
\hline Johor & 17.9 & 3.5 & 15.0 & 8.4 & 55.5 & 7.0 & 10.6 & 100 \\
\hline FT Kuala Lumpur & 14.3 & 11.4 & 36.1 & 21.5 & 9.2 & 14.9 & 6.9 & 100 \\
\hline Pulau Pinang & 7.4 & 5.9 & 12.7 & 11.4 & 67.2 & 0.4 & 2.4 & 100 \\
\hline Sarawak & 7.3 & 2.5 & 16.3 & 7.9 & 21.6 & 46.5 & 5.3 & 100 \\
\hline Sabah & 7.1 & 6.6 & 4.8 & 5.0 & 8.8 & 50.4 & 24.4 & 100 \\
\hline Perak & 4.6 & 5.3 & 7.6 & 8.9 & 49.5 & 20.1 & 8.6 & 100 \\
\hline Negeri Sembilan & 2.9 & 5.0 & 11.9 & 16.9 & 45.1 & 11.6 & 9.5 & 100 \\
\hline Melaka & 2.8 & 5.6 & 18.2 & 12.7 & 47.8 & 4.6 & 11.0 & 100 \\
\hline Pahang & 2.3 & 5.0 & 9.7 & 10.8 & 13.1 & 36.7 & 24.8 & 100 \\
\hline Kedah & 1.9 & 5.5 & 12.5 & 13.6 & 56.7 & 5.1 & 6.6 & 100 \\
\hline Terengganu & 0.5 & 7.7 & 10.6 & 21.7 & 10.6 & 47.1 & 2.3 & 100 \\
\hline FT Putrajaya & 0.5 & 6.6 & 6.8 & 12.8 & 0.2 & 67.1 & 6.6 & 100 \\
\hline Kelantan & 0.4 & 12.3 & 4.1 & 8.5 & 27.9 & 44.9 & 2.3 & 100 \\
\hline Perlis & 0.2 & 5.4 & 4.3 & 33.1 & 28.1 & 12.0 & 17.2 & 100 \\
\hline FT Labuan & 0.1 & 32.8 & 20.3 & 27.3 & 1.0 & - & 18.7 & 100 \\
\hline Total & 100 & 7.2 & 18.6 & 13.6 & 36.7 & 15.2 & 8.8 & 100 \\
\hline
\end{tabular}

Source: Ministry of Home Affairs

Indonesians are the largest foreign worker population in these two states that share borders with Indonesia on the island of Borneo. As shown in Figure 4, 70 percent of the foreign workers in Johor are Indonesians and Nepalese. Bangladeshi workers do not exceed 20 percent of the total foreign worker population in any state except the Federal Territories of Kuala Lumpur (the capital) and Putrajaya (the government administration city). Sarawak and Sabah used to be key host states in the past, when foreign workers were mainly concentrated in the agriculture and plantation sectors (Del Carpio et. al, 2015). Similarly, Thai workers are the majority in Perlis which has Thailand on its northern border, and Filipinos are numerous in Labuan Federal Territory, which is close to the Philippines. 
Figure 4: Distribution of foreign worker nationalities by state (percent, an average during March 2017- February 2018)

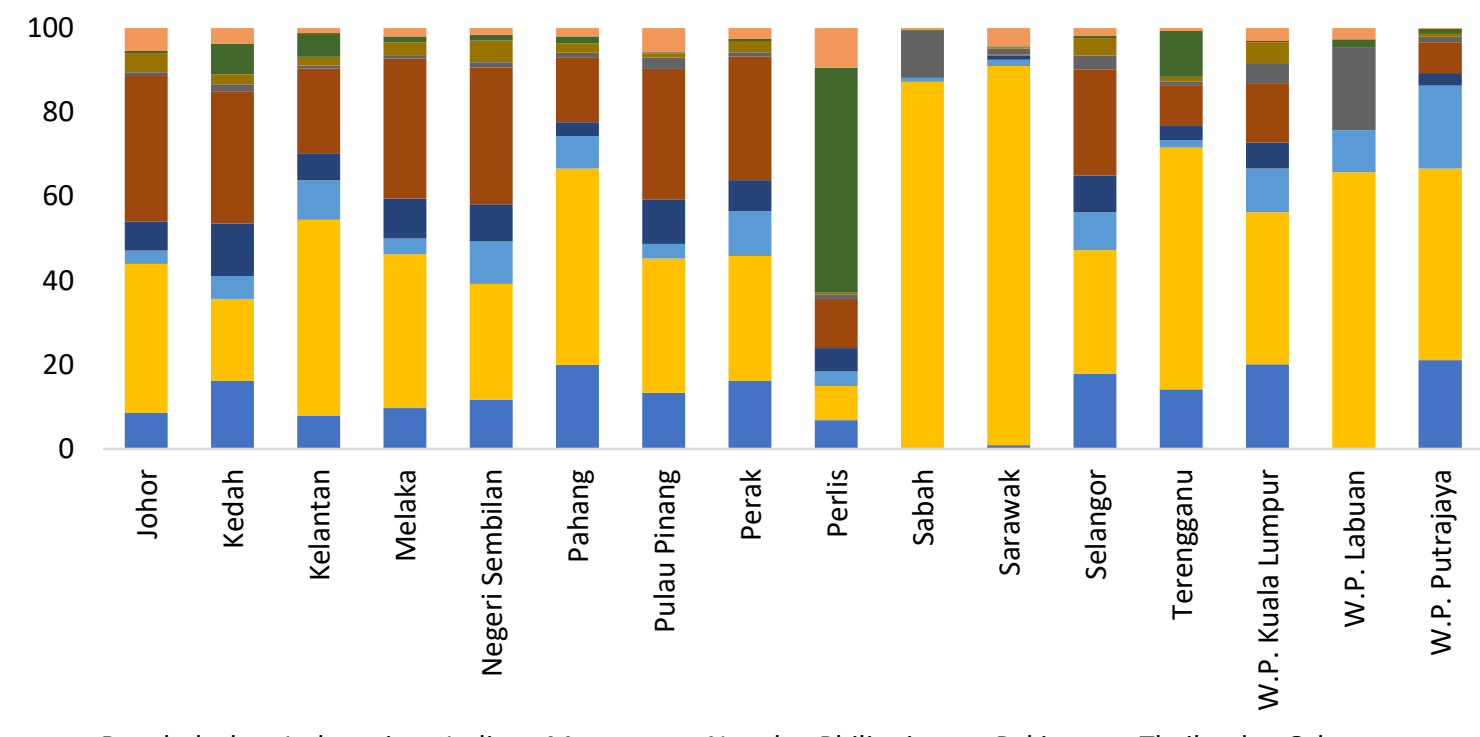

Bangladesh $\square$ Indonesia $\square$ India $\square$ Myanmar $\square$ Nepal $\square$ Philippines $\square$ Pakistan $\square$ Thailand $\square$ Others

Source: MOHA, 2017-18.

\section{Data and Methodology}

\subsection{Data}

The principal data source used is a transaction-level dataset of remittances obtained from BNM. Since 2016, BNM has compiled outbound remittance transaction data reported by remittance service providers (RSPs) as part of its banking supervision responsibilities. These include transactions carried out by post offices, money changers, and money wholesalers, but excludes those by commercial banks. Furthermore, the dataset does not include informal remittance transactions such as cash carried out by a traveler or sent through an informal money transfer channel (e.g., hawala ${ }^{4}$ ).

The data are individual daily transactions for the period of March 2017 through February 2018. The RSP data include objectively known variables for each transaction such as unique identifiers of remitters, remittance amount, transaction currency, destination country of the transfer, and the state location of MSPs. It also contains other variables, such as occupation and employment sector of the remitter, which are recorded during the account registration process at the MSPs. We do not use these variables in this paper, as the information could be outdated or incorrect.

\subsection{Methodology}

\footnotetext{
${ }^{4}$ Hawala is an informal method of transferring money without the movement of cash, but through transactions across a network of money brokers: To illustrate, a money sender goes to a money broker $A$ in the current location and gives a transaction amount to be sent to the recipient in another location; a hawala broker $B$ in that location pays out the amount to the recipient, under the promise that broker A settles the debt at a later date.
} 
The focus of this work is to identify individuals who, through the remittance data, appear to be foreign workers or carrying out transactions on behalf of other foreign workers. Unlike our earlier work (World Bank, 2020), this exercise does not attempt to identify individuals who appear to be irregular workers (see Annex 1 for a comparison of methodologies used). Rather, the main objective is to estimate the total number of foreign workers between March 2017 and February 2018, looking at the monthly numbers as well as the annual average size of the foreign worker population. Additionally, the current method uses the difference between the remittance analysis and lawfully-employed foreign population data from MOHA to estimate potential irregular workers. The specific steps are described below.

Step 1. Create a sample of potential foreign workers using objective variables of individual observations (remittance transactions).

(i) We restrict the sample to individual remitters between the ages of 18 and 55 years. According to Malaysia's foreign worker system, foreign workers must be between the ages of 18 and 45 years at the time of their work permit application, and they are allowed to stay in Malaysia for up to 10 years from their entry.

(ii) Remittances from Malaysian citizens are excluded except in cases where the remitter sends money to multiple recipients in different countries indicating employment as the source of funds, which may indicate that the transaction was done on behalf of multiple foreign workers.

(iii) As in World Bank (2020), we exclude those individuals whose monthly remittance amount is more than US\$650 (two standard deviations above the mean), as the average monthly wage of foreign workers is not more than US\$650. As a point of reference, the World Bank KNOMAD surveys (2015) show that Vietnamese workers in the manufacturing sector send, on average, US\$200/month to their family members back home.

(iv) We exclude observations with transaction amounts of RM5,000 or more (equivalent to about three months' salary of an ordinary foreign worker). The World Bank Greenback 2.0 surveys find that foreign workers send money home at least once every two months.

Step 2. Identify transactions undertaken on behalf of others in each month and record them as transactions done by different individuals. We treat the following transactions as those done by another individual:

(i) The third or subsequent transactions by an individual within a month, assuming that foreign workers send money home, on average, twice a month at most, as each transaction entails remittance costs and they are sensitive to these costs.

(ii) Second or subsequent transactions by an individual on the same day.

(iii) Transfers to a country that is different from the remitter's nationality.

(iv) Transfers made by a Malaysian to various destination countries. For example, most of these cases specify that the purpose of the transfer is "family maintenance" and the source of funding as "employee salary" or "others' income." 
Step 3. Tabulate summary statistics of individuals and dummy variables by nationality and state.

The share and number of foreign workers are computed by main nationality and state, and by month from March 2017 through February 2018. We also take an annual average distribution.

Step 4. Make adjustments to the remittance statistics and compare the results obtained from remittance data analysis with the official numbers reported by MOHA.

Based on the remittance analysis, we make additional adjustments to estimate the total number of foreign workers in Malaysia. As earlier in World Bank (2020), we recognize that not all foreign workers use MSPs to remit their earnings back home, and thus assume that the remittance data represent 77 percent of the foreign worker population, based on the World Bank Greenback 2.0 surveys of foreign workers in Johor that finds that about 77 percent of foreign workers use MSPs to transfer money (World Bank, 2017). Then, the final estimated foreign worker population is compared with MOHA's figures on work permit holders, using annual averages, to find the estimated number of irregular workers between March 2017 and February 2018.

Step 5. Robustness check to provide a lower-bound estimate of the number of foreign workers.

As a robustness check of our initial estimations, we took the share of foreign workers by nationality in each state from the MOHA data, and then applied these shares to the total number of foreign workers at the state level we obtained from the remittance data (the figure prior to adjusting using the 77 percent remitter proportion in Step 4). After recalibrating the monthly numbers of foreign worker population by nationality, we calculated the differences in the number of foreign workers in each state between our results and the MOHA data. When the differences are negative (that is, the number of foreign workers in the remittance dataset is smaller than in the MOHA data), we apply that the differences are zero. In other words, the number of foreign workers for a specific nationality in a given state from the remittance dataset equals that from the MOHA dataset. This is to correct that this method does not adjust for the 77 percent of the foreign worker population who use MSP channels to send money. As noted earlier, not all foreign workers have access to MSPs or they may use of alternative channels for various reasons. We add the nationality-specific differences to the MOHA data to estimate the size of the potential foreign worker population in Malaysia. This method could generate an upward bias but cases where the differences are negative are few and the negative differences are small. Therefore, it is more likely to underestimate by not fully adjusting those 'missing' foreign workers (who do not use MSPs) in nationality groups where differences are positive.

\section{Results}

Our estimates suggest that the total foreign worker population was between 2.99 million and 3.16 million during the period of March 2017 to February 2018, a narrower range than our earlier estimates in World Bank (2020). Firstly, we identified 2.43 million individuals who are potentially foreign workers in the remittance analysis and then adjusted the estimate on the assumption that the remittance data represent 77 percent of the foreign worker population (as explained earlier in Step 4), thus leading to 3.16 
million foreign workers in total. As the MOHA work permit data indicates 1.77 million foreign workers during the period, the first estimate implies that the number of irregular foreign workers is approximately 1.39 million. Secondly, our robustness check (Step 5 under 'Methodology') estimates a foreign worker population of 2.99 million, of which 1.22 million are irregulars (see Figure 5 on the number by nationality).

Figure 5. Estimated number of foreign workers by nationality

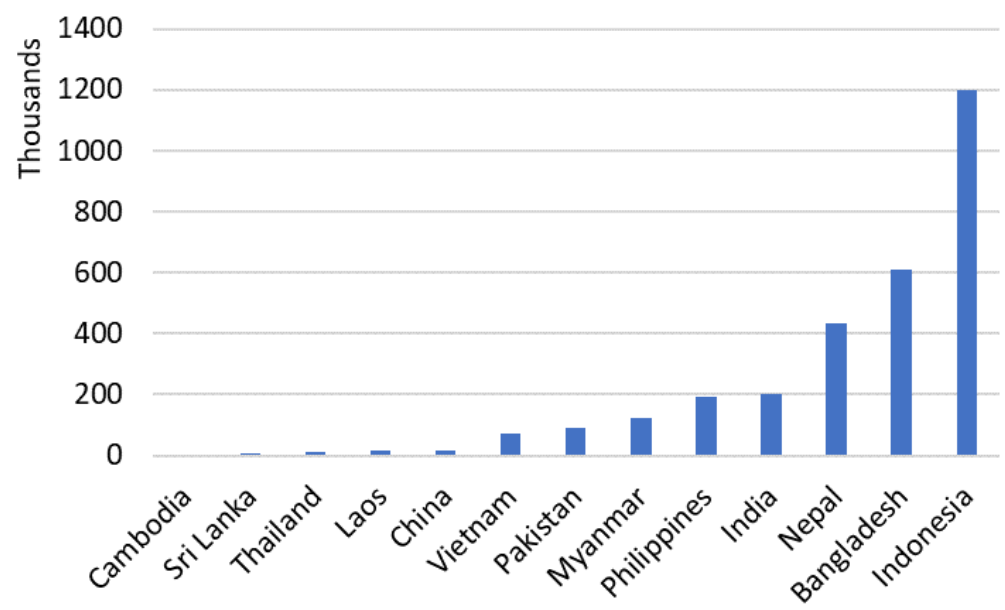

Source: BNM remittance data, authors' estimations.

The distribution of foreign workers by state in our estimates are in line with those reported in the MOHA data. Foreign workers are concentrated in Selangor, followed by Johor and Kuala Lumpur Federal Territory (Figure 6a). Interestingly, we find that Sarawak takes up a substantially lower share of the foreign worker population in our estimates compared to the MOHA data - 3 percent of the total versus 7 percent (Figure 6b). It may be that foreign workers in Sarawak have a lower propensity to use remittance outlets because of limited accessibility in Sarawak, or that foreign workers in Sarawak opt for alternative money transfer channels such as cash carried by a traveler going back home.

As in the MOHA data, Indonesians make up most of the foreign worker population in our estimates (Figure 7a). However, the second largest group as estimated from the remittance data is not Nepalese but Bangladeshis. This might be explained by two plausible scenarios: (i) not many Nepalese use MSPs, instead using alternative channels to send money, especially in Selangor, and (ii) a higher proportion of Bangladeshis are irregular workers than are Nepalese. Also, our estimates from the remittance data show smaller numbers of Myanmar, Thai, and Chinese foreign workers compared to MOHA's data (Figure 7b). Chinese foreign workers are known to use banking channels, possibly because they tend to earn more than average foreign workers ${ }^{5}$ and thus can afford higher remittance costs, or because the availability of MSP counterparts in China is limited. Filipinos take up a larger share in our results than in the MOHA dataset, perhaps in line with anecdotal evidence that Filipinos in general have a higher level of financial

\footnotetext{
${ }^{5}$ Based on our analysis of the average annual remittance amount by nationality, most of the individual remitters send home RM 3,000 and below per annum, except for remittance transactions to China and Vietnam.
} 
literacy than other foreign worker groups and thus tend to use MSPs to send money home which, on average, charge lower remittance fees than commercial bank channels.

Figure 6. Distribution of foreign workers by state as estimated from the BNM remittance data and as reported in the MOHA data

\section{(a) BNM remittance data}

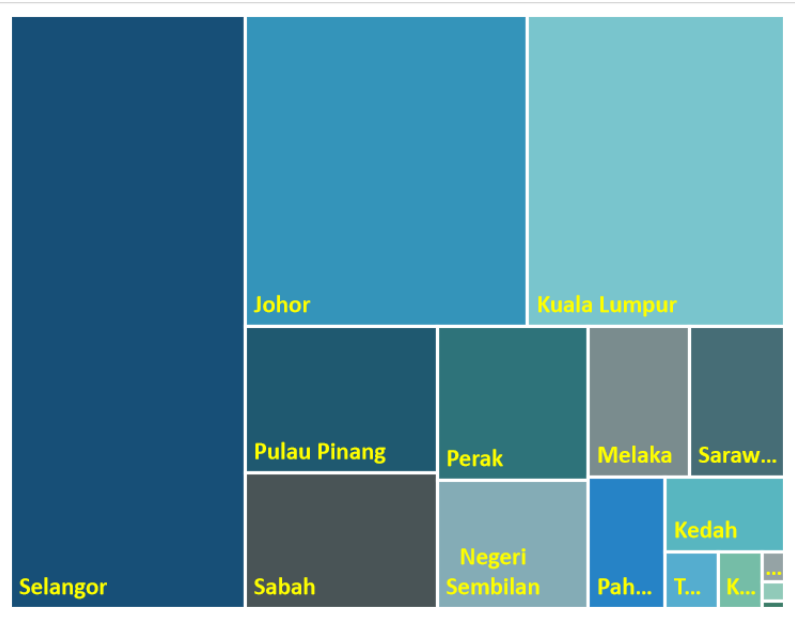

Source: BNM remittance data, authors' estimations.

\section{(b) Comparison of two data sources (percent)}

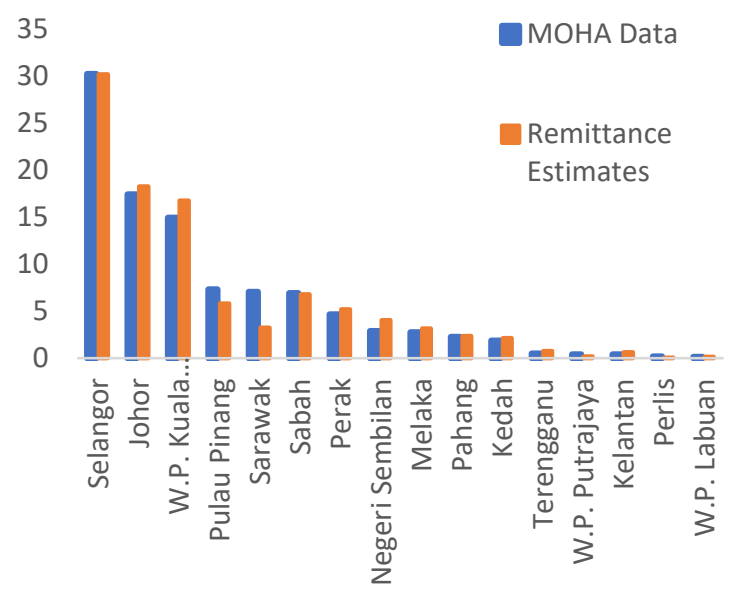

Figure 7. Distributions of foreign workers by nationality in the BNM remittance data - broadly consistent with MOHA data

(a) BNM remittance data

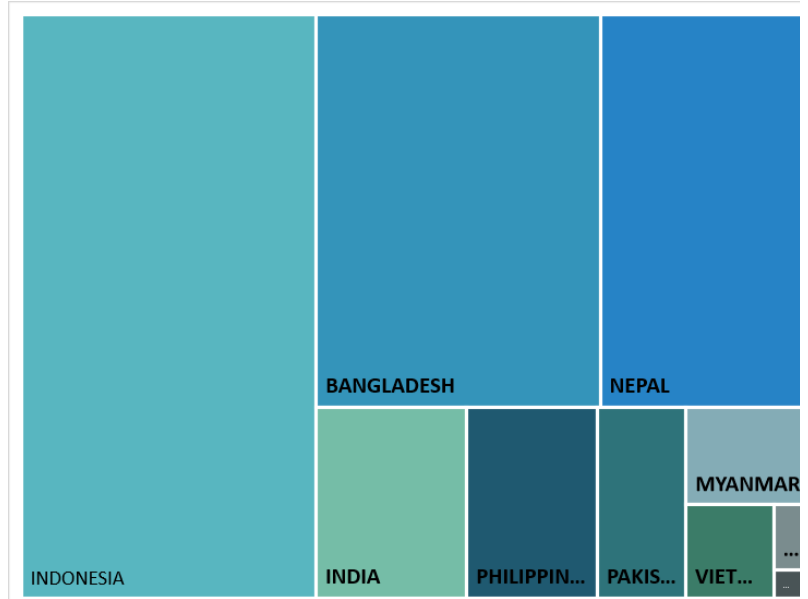

(b) Comparison of two data sources (percent)

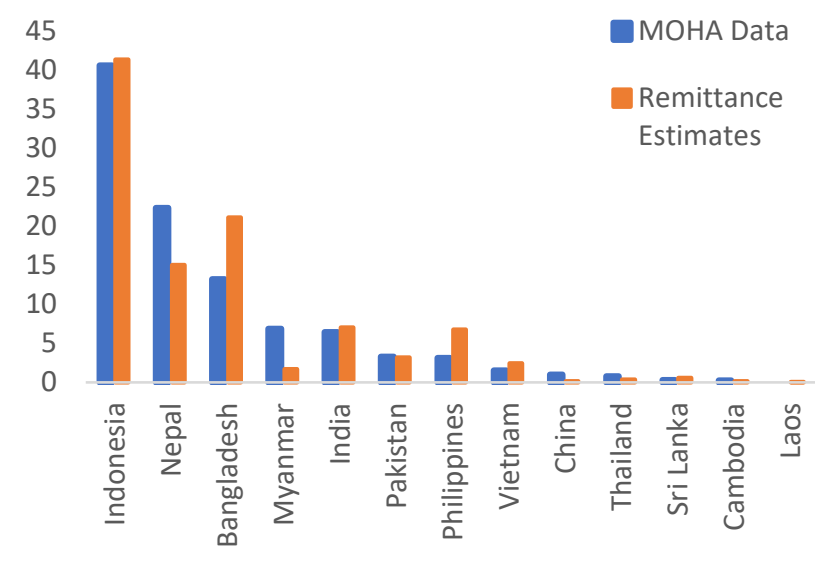

Source: MOHA, Bank Negara Malaysia, authors' calculations. 


\section{Conclusions}

This paper aims to provide new information to support the Malaysian government in formulating evidence-based policies on foreign workers. Anecdotal evidence suggests that the COVID-19 pandemic has had large negative effects on foreign workers in Malaysia. For example, foreign workers who are laid off because of contractions in business activities related to the $\mathrm{MCO}$ or the pandemic more broadly are not legally allowed to be employed by other companies while remaining in Malaysia. At the same time, many cannot go back to their home countries because of travel restrictions as a COVID-19 mitigation measure. Furthermore, irregular foreign workers have limited access to public medical facilities and treatment, posing health risks. Foreign worker estimates by nationality and by state thus could help formulate policies on how to reallocate existing foreign workers in the country and on how to adjust foreign worker levies and new inflows of foreign workers during the MCO phase and thereafter. Such policies would help the government to strengthen the economy in the recovery phase of the COVID-19 crisis.

We demonstrate that the BNM remittance dataset is a useful source to estimate the number of foreign workers on a monthly basis, using a 12-month moving average. Our experience suggests that simple monthly data is too volatile for these purposes as some foreign workers remit on an irregular basis. To smooth out fluctuations in monthly data and to capture an annual net stock of foreign workers, a 12month moving average would be an appropriate method. The initial work to try to identify individuals who transfer money on behalf of others is time-intensive, but once this model is set up, big hurdles would be lifted and thus it would be relatively straightforward to produce monthly estimates and future projections on a timely basis. In that context, our work contributes to making progress in the initial setting up stage. During this exercise, it is important to ensure data privacy of individual remitters. Bearing this in mind, we used MSP system-generated personal unique identification numbers as a variable for remitters.

Our estimates suggest that the number of foreign workers in Malaysia was between 2.99 and 3.16 million in 2017-18. State and nationality distributions of foreign workers in our estimates are consistent with the MOHA data, lending support to the validity of our estimates. Nevertheless, we note that the BNM remittance data could potentially underestimate the number of workers in states with low access to MSPs, as well as nationalities that have access to alternative money transfer mechanisms such as commercial banking and informal transfer channels. This risk could be mitigated over time by BNM's greater efforts to enhance financial literacy of residents, including foreign workers, and increase the availability of online remittance services to ease accessibility and further reduce remittance costs. As a complementary measure, BNM could conduct annual foreign worker surveys to better understand their financial management behavior, leveraging the existing network of MSPs. 


\section{References}

Abdul-Rahman, H., Wang, C., Wood, L. C., Low, S. F. 2012. "Negative impact induced by foreign workers: Evidence in Malaysian construction sector," Habitat International 36(4), pp. 433-443.

del Carpio, Ximena, Çağlar Özden, Mauro Testaverde, and Mathis Wagner. 2015. "Local Labor Supply Responses to Immigration," The Scandinavian Journal of Economics 117(2):493-521.

Department of Statistics Malaysia (DOSM). 2019. Labor Force Survey Report 2018.

2019. "Current Population Estimates, Malaysia, 2018-2019." https://www.dosm.gov.my/v1/index.php?r=column/cthemeByCat\&cat=155\&bul_id=aWJZRkJ4UE dKcUZpT2tVT090Snpydz09\&menu_id=LOpheU43NWJwRWVSZkIWdzQ4TIhUUT09.

Immigration Department of Malaysia. 2020. "Foreign Worker." Ministry of Home Affairs, Malaysia: https://www.imi.gov.my/index.php/en/foreign-worker.html.

The Jakarta Post. April 23 2020. "High influx of Indonesian migrant workers from Malaysia, despite call to stay amid outbreak." Retrieved from https://www.thejakartapost.com/news/2020/04/23/highinflux-of-indonesian-migrant-workers-from-malaysia-despite-call-to-stay-amid-outbreak.html.

World Bank. 2015. "Malaysia Economic Monitor December 2015: Immigrant Labour." Washington, DC: The World Bank.

2016. "Understanding the Malaysian Labour Market and Foreign Labour: The Past, Present and Future Role of Foreign Workers in the Economy." Report commissioned by the Economic Planning Unit of the Government of Malaysia.

2017. "Greenback 2.0 Johor Bahru Report: migrant workers' remittances from Malaysia." Kuala Lumpur: The World Bank.

World Bank. 2020. "Who is Keeping Score? Estimating the Number of Foreign Workers in Malaysia." Kuala Lumpur: The World Bank. 


\section{Annex 1. Methodologies to estimate the number of foreign workers}

\begin{tabular}{|c|c|c|c|c|}
\hline & \multicolumn{3}{|c|}{ Previous approaches (World Bank 2020) ${ }^{6}$} & \multirow{2}{*}{$\begin{array}{c}\text { Current approach } \\
\text { BNM Remittance data }\end{array}$} \\
\hline & $\begin{array}{l}\text { Administrative data - } \\
\text { Residual approach }\end{array}$ & $\begin{array}{l}\text { Administrative data - } \\
\text { Build-up approach }\end{array}$ & $\begin{array}{l}\text { BNM Remittance } \\
\text { data }\end{array}$ & \\
\hline Data & $\begin{array}{l}\text { VP(TE) permits/passes } \\
\text { issuance and IMM13 } \\
\text { issuance data by MOHA; } \\
\text { Population and Housing } \\
\text { Census 2010; and } \\
\text { assumptions on } \\
\text { undercount based on } \\
\text { Kanapathy (2008), } \\
\text { Woodrow (1991), and } \\
\text { US DHS (2018) }\end{array}$ & $\begin{array}{l}\text { Labor Force Survey; } \\
\text { VP(TE) permits/passes } \\
\text { issuance and IMM13 } \\
\text { issuance data by } \\
\text { MOHA; and } \\
\text { assumptions based on } \\
\text { the } 6 \mathrm{P} \text { and rehiring } \\
\text { programs by the } \\
\text { Immigration } \\
\text { Department }\end{array}$ & $\begin{array}{l}\text { Monthly remittance } \\
\text { transactions } \\
\text { reported by money } \\
\text { service providers } \\
\text { (MSPs) and } \\
\text { managed by Bank } \\
\text { Negara Malaysia }\end{array}$ & $\begin{array}{l}\text { Monthly remittance } \\
\text { transactions reported } \\
\text { by money service } \\
\text { providers (MSPs) and } \\
\text { managed by Bank } \\
\text { Negara Malaysia; and } \\
\text { monthly data on stock } \\
\text { of foreign worker } \\
\text { population by MOHA }\end{array}$ \\
\hline Type of data & Aggregate-level & Aggregate-level & Micro-level & $\begin{array}{l}\text { Micro-level and } \\
\text { monthly aggregate } \\
\text { data }\end{array}$ \\
\hline Methodology & $\begin{array}{l}\text { Difference between } \\
\text { lawfully employed } \\
\text { foreign population and } \\
\text { total foreign-born } \\
\text { population, including } \\
\text { undercount of foreign } \\
\text { workers, refugees and } \\
\text { asylees, and irregular } \\
\text { immigrants }\end{array}$ & $\begin{array}{l}\text { Difference between } \\
\text { non-citizen population } \\
\text { in LFS and lawfully } \\
\text { employed foreign } \\
\text { population, plus the } \\
\text { addition/subtraction of } \\
\text { annual flow estimates } \\
\text { for irregulars through } \\
\text { rehiring programs/ } \\
\text { enforcement } \\
\text { operations }\end{array}$ & $\begin{array}{l}\text { Estimate the total } \\
\text { and irregular foreign } \\
\text { worker population } \\
\text { using monthly } \\
\text { remittance } \\
\text { transactions and } \\
\text { senders' } \\
\text { characteristics } \\
\text { (nationality, } \\
\text { destination country, } \\
\text { transaction amount) }\end{array}$ & $\begin{array}{l}\text { Estimate the annual } \\
\text { average foreign worker } \\
\text { population using } \\
\text { monthly remittance } \\
\text { transactions, then } \\
\text { taking the difference } \\
\text { between this and } \\
\text { lawfully employed } \\
\text { foreign population to } \\
\text { estimate irregulars }\end{array}$ \\
\hline Results & $\begin{array}{l}1.46 \text { million irregulars, in } \\
2017\end{array}$ & $\begin{array}{l}1.23 \text { million irregulars, } \\
\text { in } 2017\end{array}$ & $\begin{array}{l}2.96 \text { million total } \\
\text { and } 1.42 \text { million } \\
\text { irregulars, between } \\
\text { March } 2017- \\
\text { February } 2018\end{array}$ & $\begin{array}{l}2.99-3.16 \text { million total } \\
\text { and } 1.22-1.39 \text { million } \\
\text { irregulars, between } \\
\text { March 2017-February } \\
2018\end{array}$ \\
\hline Limitations & $\begin{array}{l}\text { Underestimation is likely } \\
\text { to occur because of } \\
\text { limited data sources and } \\
\text { undercount of irregular } \\
\text { foreign population in } \\
\text { both the DOSM census } \\
\text { and MOHA data }\end{array}$ & $\begin{array}{l}\text { Underestimation due } \\
\text { to exclusion of workers } \\
\text { in communal housing } \\
\text { (LFS) and } \\
\text { overestimation that all } \\
\text { unmet labor demands } \\
\text { is filled by new inflows } \\
\text { of irregulars }\end{array}$ & $\begin{array}{l}\text { Underestimation } \\
\text { because remittance } \\
\text { data does not } \\
\text { capture workers } \\
\text { who use alternative } \\
\text { channels (such as } \\
\text { online money } \\
\text { transfers and/or } \\
\text { cash) to send money } \\
\text { home }\end{array}$ & $\begin{array}{l}\text { Underestimation } \\
\text { because remittance } \\
\text { data does not capture } \\
\text { workers who use } \\
\text { alternative channels } \\
\text { and undercount of } \\
\text { irregulars in } \mathrm{MOHA} \\
\text { data }\end{array}$ \\
\hline
\end{tabular}

\footnotetext{
${ }^{6}$ World Bank. 2020. "Who is Keeping Score? Estimating the Number of Foreign Workers in Malaysia." Kuala Lumpur: The World Bank.
} 


\section{Annex 2. Use of the remittance transaction amount variable}

We attempted to estimate potential irregular foreign workers using the remittance amount variable in the remittance dataset but this did not yield satisfactory results. It may be reasonably assumed that regular foreign workers have steady streams of salary income and therefore would send home a similar amount each time. On the other hand, irregular foreign workers would have less job security and be more vulnerable to job losses or variable number of working days, and thus are likely to have more volatile income flows and varying remittance amounts. Thus, one could assume that remittance amounts that are more than one standard deviation from the mean remittance amount of each nationality group could be made by irregular foreign workers (Figure 9). However this approach generated unreasonably low figures for the number of irregular foreign workers.

Figure 9. Average annual remittance amount of an individual by nationality (RM)

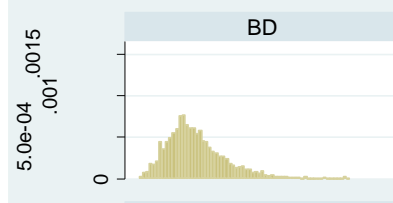

$\mathrm{KH}$

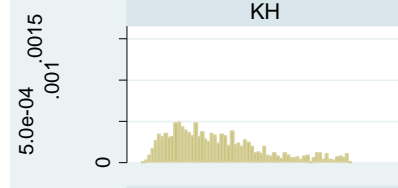

$\mathrm{PH}$

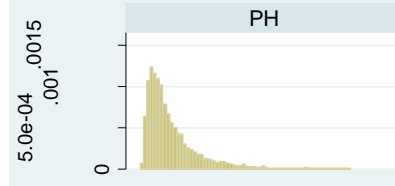

VN

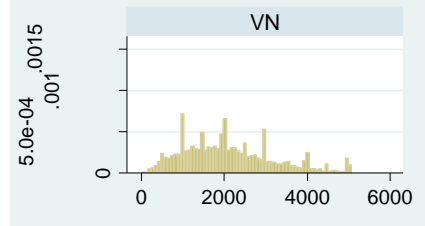

Graphs by (firstnm) nationality
$\mathrm{CN}$

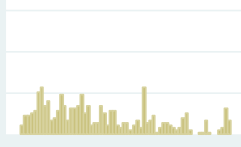

LK

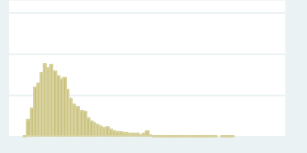

PK
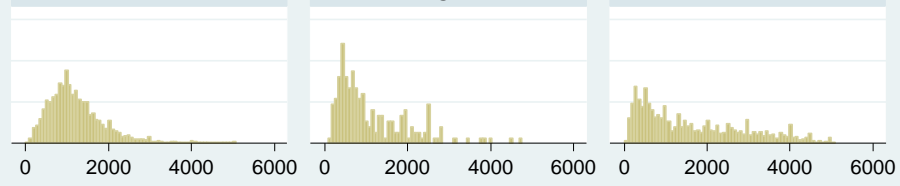

IN

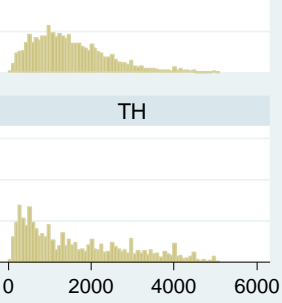

NP

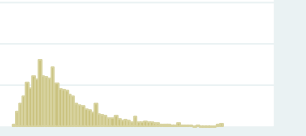

ID

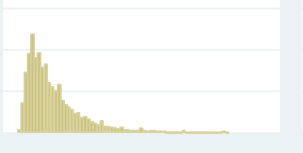

MM

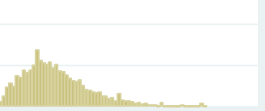

SL

(mean) rm_amt

Source: BNM remittance data, authors' calculations. 